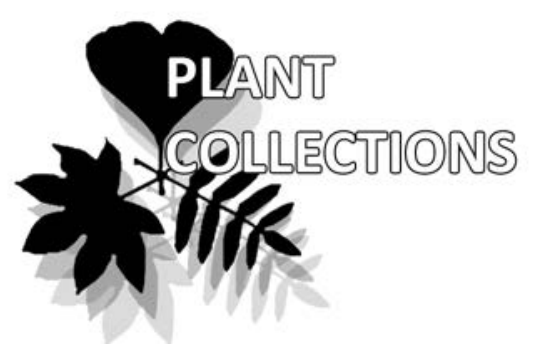

Evgeniya A. Gatilova

e-mail: zhenya_kl@mail.ru

Irina V. Han

e-mail: irahan81@gmail.com

Nataliya K. Kovtonyuk *

e-mail:knat2008@yandex.ru

Central Siberian Botanical Garden SB RAS, Novosibirsk, Russia

* corresponding author

Manuscript received: 28.08 .2021

Review completed: 07.08 .2021

Accepted for publication: 30.09.2021

Published online: 14.10.2021

\section{Biological collections: An inventory of Russian Far East section in I.M. Krasnoborov Herbarium (NS)}

\author{
Evgeniya A. Gatilova, Irina V. Han \& Nataliya K. Kovtonyuk*
}

\begin{abstract}
A B S T R A C T
A complete inventory of the Russian Far East section of the vascular plants collec-
tion stored at the Krasnoborov Herbarium (NS) of the Central Siberian Botanical
Garden SB RAS was made. As a result, 4423 untecorded herbarium sheets and 457
previously unregistered species were added to the collection. Type specimens of 4
taxa which had been described from the Russian Far East were found and digitized:
Anemone tamarae Kharkev., Chrysosplenium schagae Kharkev. \& Vyschin, Potentilla anju-
ica V.V. Petrovsky u Tephroseris schistosa (Kharkev.) Barkalov. The updated catalogue
of the collection, consisting of 3248 taxa, was published on the Global Biodiversity
Information Facility portal, GBIF.org. A taxonomic and historical analysis of the
collections, as well as a list of the leading collectors, is presented.
Keywords: biological collections, herbarium, history, catalogue, Russia, vascular plants,
taxonomy, GBIF
A B S T R A C T
A complete inventory of the Russian Far East section of the vascular plants collec-
tion stored at the Krasnoborov Herbarium (NS) of the Central Siberian Botanical
Garden SB RAS was made. As a result, 4423 untecorded herbarium sheets and 457
previously unregistered species were added to the collection. Type specimens of 4
taxa which had been described from the Russian Far East were found and digitized:
Anemone tamarae Kharkev., Chrysosplenium schagae Kharkev. \& Vyschin, Potentilla amju-
ica V.V. Petrovsky u Tephroseris schistosa (Kharkev.) Barkalov. The updated catalogue
of the collection, consisting of 248 taxa, was published on the Global Biodiversity
Information Facility portal, GBIF.org. A taxonomic and historical analysis of the
collections, as well as a list of the leading collectors, is presented.
Keywords: biological collections, herbarium, history, catalogue, Russia, vascular plants,
taxonomy, GBIF

A B S T R A C T
A complete inventory of the Russian Far East section of the vascular plants collec-
tion stored at the Krasnoborov Herbarium (NS) of the Central Siberian Botanical
Garden SB RAS was made. As a result, 4423 untecorded herbarium sheets and 457
previously unregistered species were added to the collection. Type specimens of 4
taxa which had been described from the Russian Far East were found and digitized:
Anemone tamarae Kharkev., Chrysosplenium schagae Kharkev. \& Vyschin, Potentilla amju-
ica V.V. Petrovsky u Tephroseris schistosa (Kharkev.) Barkalov. The updated catalogue
of the collection, consisting of 248 taxa, was published on the Global Biodiversity
Information Facility portal, GBIF.org. A taxonomic and historical analysis of the
collections, as well as a list of the leading collectors, is presented.
Keywords: biological collections, herbarium, history, catalogue, Russia, vascular plants,
taxonomy, GBIF

A B S T R A C T
A complete inventory of the Russian Far East section of the vascular plants collec-
tion stored at the Krasnoborov Herbarium (NS) of the Central Siberian Botanical
Garden SB RAS was made. As a result, 4423 untecorded herbarium sheets and 457
previously unregistered species were added to the collection. Type specimens of 4
taxa which had been described from the Russian Far East were found and digitized:
Anemone tamarae Kharkev., Chrysosplenium schagae Kharkev. \& Vyschin, Potentilla amju-
ica V.V. Petrovsky u Tephroseris schistosa (Kharkev.) Barkalov. The updated catalogue
of the collection, consisting of 248 taxa, was published on the Global Biodiversity
Information Facility portal, GBIF.org. A taxonomic and historical analysis of the
collections, as well as a list of the leading collectors, is presented.
Keywords: biological collections, herbarium, history, catalogue, Russia, vascular plants,
taxonomy, GBIF

A B S T R A C T
A complete inventory of the Russian Far East section of the vascular plants collec-
tion stored at the Krasnoborov Herbarium (NS) of the Central Siberian Botanical
Garden SB RAS was made. As a result, 4423 untecorded herbarium sheets and 457
previously unregistered species were added to the collection. Type specimens of 4
taxa which had been described from the Russian Far East were found and digitized:
Anemone tamarae Kharkev., Chrysosplenium schagae Kharkev. \& Vyschin, Potentilla amju-
ica V.V. Petrovsky u Tephroseris schistosa (Kharkev.) Barkalov. The updated catalogue
of the collection, consisting of 248 taxa, was published on the Global Biodiversity
Information Facility portal, GBIF.org. A taxonomic and historical analysis of the
collections, as well as a list of the leading collectors, is presented.
Keywords: biological collections, herbarium, history, catalogue, Russia, vascular plants,
taxonomy, GBIF

A B S T R A C T
A complete inventory of the Russian Far East section of the vascular plants collec-
tion stored at the Krasnoborov Herbarium (NS) of the Central Siberian Botanical
Garden SB RAS was made. As a result, 4423 untecorded herbarium sheets and 457
previously unregistered species were added to the collection. Type specimens of 4
taxa which had been described from the Russian Far East were found and digitized:
Anemone tamarae Kharkev., Chrysosplenium schagae Kharkev. \& Vyschin, Potentilla amju-
ica V.V. Petrovsky u Tephroseris schistosa (Kharkev.) Barkalov. The updated catalogue
of the collection, consisting of 248 taxa, was published on the Global Biodiversity
Information Facility portal, GBIF.org. A taxonomic and historical analysis of the
collections, as well as a list of the leading collectors, is presented.
Keywords: biological collections, herbarium, history, catalogue, Russia, vascular plants,
taxonomy, GBIF

A B S T R A C T
A complete inventory of the Russian Far East section of the vascular plants collec-
tion stored at the Krasnoborov Herbarium (NS) of the Central Siberian Botanical
Garden SB RAS was made. As a result, 4423 untecorded herbarium sheets and 457
previously unregistered species were added to the collection. Type specimens of 4
taxa which had been described from the Russian Far East were found and digitized:
Anemone tamarae Kharkev., Chrysosplenium schagae Kharkev. \& Vyschin, Potentilla amju-
ica V.V. Petrovsky u Tephroseris schistosa (Kharkev.) Barkalov. The updated catalogue
of the collection, consisting of 248 taxa, was published on the Global Biodiversity
Information Facility portal, GBIF.org. A taxonomic and historical analysis of the
collections, as well as a list of the leading collectors, is presented.
Keywords: biological collections, herbarium, history, catalogue, Russia, vascular plants,
taxonomy, GBIF

A B S T R A C T
A complete inventory of the Russian Far East section of the vascular plants collec-
tion stored at the Krasnoborov Herbarium (NS) of the Central Siberian Botanical
Garden SB RAS was made. As a result, 4423 untecorded herbarium sheets and 457
previously unregistered species were added to the collection. Type specimens of 4
taxa which had been described from the Russian Far East were found and digitized:
Anemone tamarae Kharkev., Chrysosplenium schagae Kharkev. \& Vyschin, Potentilla amju-
ica V.V. Petrovsky u Tephroseris schistosa (Kharkev.) Barkalov. The updated catalogue
of the collection, consisting of 248 taxa, was published on the Global Biodiversity
Information Facility portal, GBIF.org. A taxonomic and historical analysis of the
collections, as well as a list of the leading collectors, is presented.
Keywords: biological collections, herbarium, history, catalogue, Russia, vascular plants,
taxonomy, GBIF

A B S T R A C T
A complete inventory of the Russian Far East section of the vascular plants collec-
tion stored at the Krasnoborov Herbarium (NS) of the Central Siberian Botanical
Garden SB RAS was made. As a result, 4423 untecorded herbarium sheets and 457
previously unregistered species were added to the collection. Type specimens of 4
taxa which had been described from the Russian Far East were found and digitized:
Anemone tamarae Kharkev., Chrysosplenium schagae Kharkev. \& Vyschin, Potentilla amju-
ica V.V. Petrovsky u Tephroseris schistosa (Kharkev.) Barkalov. The updated catalogue
of the collection, consisting of 248 taxa, was published on the Global Biodiversity
Information Facility portal, GBIF.org. A taxonomic and historical analysis of the
collections, as well as a list of the leading collectors, is presented.
Keywords: biological collections, herbarium, history, catalogue, Russia, vascular plants,
taxonomy, GBIF

A B S T R A C T
A complete inventory of the Russian Far East section of the vascular plants collec-
tion stored at the Krasnoborov Herbarium (NS) of the Central Siberian Botanical
Garden SB RAS was made. As a result, 4423 untecorded herbarium sheets and 457
previously unregistered species were added to the collection. Type specimens of 4
taxa which had been described from the Russian Far East were found and digitized:
Anemone tamarae Kharkev., Chrysosplenium schagae Kharkev. \& Vyschin, Potentilla amju-
ica V.V. Petrovsky u Tephroseris schistosa (Kharkev.) Barkalov. The updated catalogue
of the collection, consisting of 248 taxa, was published on the Global Biodiversity
Information Facility portal, GBIF.org. A taxonomic and historical analysis of the
collections, as well as a list of the leading collectors, is presented.
Keywords: biological collections, herbarium, history, catalogue, Russia, vascular plants,
taxonomy, GBIF

A B S T R A C T
A complete inventory of the Russian Far East section of the vascular plants collec-
tion stored at the Krasnoborov Herbarium (NS) of the Central Siberian Botanical
Garden SB RAS was made. As a result, 4423 untecorded herbarium sheets and 457
previously unregistered species were added to the collection. Type specimens of 4
taxa which had been described from the Russian Far East were found and digitized:
Anemone tamarae Kharkev., Chrysosplenium schagae Kharkev. \& Vyschin, Potentilla amju-
ica V.V. Petrovsky u Tephroseris schistosa (Kharkev.) Barkalov. The updated catalogue
of the collection, consisting of 248 taxa, was published on the Global Biodiversity
Information Facility portal, GBIF.org. A taxonomic and historical analysis of the
collections, as well as a list of the leading collectors, is presented.
Keywords: biological collections, herbarium, history, catalogue, Russia, vascular plants,
taxonomy, GBIF

A B S T R A C T
A complete inventory of the Russian Far East section of the vascular plants collec-
tion stored at the Krasnoborov Herbarium (NS) of the Central Siberian Botanical
Garden SB RAS was made. As a result, 4423 untecorded herbarium sheets and 457
previously unregistered species were added to the collection. Type specimens of 4
taxa which had been described from the Russian Far East were found and digitized:
Anemone tamarae Kharkev., Chrysosplenium schagae Kharkev. \& Vyschin, Potentilla amju-
ica V.V. Petrovsky u Tephroseris schistosa (Kharkev.) Barkalov. The updated catalogue
of the collection, consisting of 248 taxa, was published on the Global Biodiversity
Information Facility portal, GBIF.org. A taxonomic and historical analysis of the
collections, as well as a list of the leading collectors, is presented.
Keywords: biological collections, herbarium, history, catalogue, Russia, vascular plants,
taxonomy, GBIF

A B S T R A C T
A complete inventory of the Russian Far East section of the vascular plants collec-
tion stored at the Krasnoborov Herbarium (NS) of the Central Siberian Botanical
Garden SB RAS was made. As a result, 4423 untecorded herbarium sheets and 457
previously unregistered species were added to the collection. Type specimens of 4
taxa which had been described from the Russian Far East were found and digitized:
Anemone tamarae Kharkev., Chrysosplenium schagae Kharkev. \& Vyschin, Potentilla amju-
ica V.V. Petrovsky u Tephroseris schistosa (Kharkev.) Barkalov. The updated catalogue
of the collection, consisting of 248 taxa, was published on the Global Biodiversity
Information Facility portal, GBIF.org. A taxonomic and historical analysis of the
collections, as well as a list of the leading collectors, is presented.
Keywords: biological collections, herbarium, history, catalogue, Russia, vascular plants,
taxonomy, GBIF

\section{P E 3 Ю M E}

Гатимова Е.А., Хан И.В., Ковтонюк Н.К. Биомогические комлекции: инвентаризация раздема Аальнего Востока России в Гербарии им. И.М. Красноборова (NS). Проведена полная инвентаризация отдела "Аальний Восток" колмекции сосудистых растений, хранящихся в гербарии им. И.М. Красноборова (NS) Центрального сибирского ботанического саАа СО РАН. В результате инвентаризации добавлены новые поступления в количестве 4423 гербарных листов и 457 ранее не отмеченных видов. Обнаружены и оцифрованы типовые образцы 4 таксонов, описанных с территории Российского Аальнего Востока: Anemone tamarae Kharkev., Chrysosplenium schagae Kharkev. \& Vyschin, Potentilla anjuica V.V. Petrovsky и Tephroseris scbistosa (Kharkev.) Barkalov. Обновленный каталог колмекции, состоящий из 3248 таксонов, опубликован на портале GBIF.org. Проведен таксономический и исторический анализ сборов, а также об̆зор ведущих колмекторов.

КАючевые смова: биологические колмекции, гербарий, история, каталог, Россия, сосудистые растения, таксономия, GBIF

(1)
\end{abstract}


lection RFE NS, which was previously stored in a small workroom. Relocation and inventory of the whole collection took about 2.5 months, of which 10 days were spent on quarantine processing of the collection.

The 4423 herbarium sheets and 457 new for the collection species were added to RFE NS. The next step of the inventory was the detailed verification of the existing catalogue of the RFE section, the herbarium boxes were renewed and all the specimens were recalculated. The excatalogue listed 8474 sheets and 2074 species of vascular plants, but the collection actually contained 11750 sheets and 2814 species. Thus, over 3000 specimens and 740 taxa were already inserted, but were not catalogued and so they could not be found and used by specialists.

By revising the herbarium boxes in the RFE NS sector, samples belonging to other regions (Yakutia, the European part of Russia, the Altaiskii Krai and the Altai Republic, the Caucasus and Central Asia) were removed. In particular, 20 herbarium specimens from the collections of D.I. Litvinov (1902-1903) were found with notes on the labels "East Manchuria" or "West Manchuria". In fact, these plants were collected along the Chinese Eastern Railway (Gatilova et al. 2020). These herbarium specimens from Litvinov's collection, as well as three specimens collected by F. Karo on the right bank of Amur River were relocated to the Foreign Asia section of the NS.

Before the inventory, the RFE NS section contained undetermined herbarium sheets prepared for inseration. Unidentified herbarium specimens were surveyed with the valuable help of taxonomists V.V. Yakubov (Federal Scientific Center of the East Asia Terrestrial Biodiversity), A.L. Ebel, I.N. Shehovtsova, N.K. Kovtonyuk, I.V. Han, N.V. Vlasova, E.A. Gatilova, Yu.V. Ovchinnikov, S.V. Ovchinnikova (Central Siberian Botanical Garden), I.V. Belyaeva (Royal Botanical Gardens, Kew, UK). Currently, the section contains 11 herbarium specimens defined only up to the genus level: Artemisia (NS0039943, NS0039944), Calamagrostis (NS0039946), Eleocharis (NS0039956), Juncus (NS0041227), Lonicera (NS0041229), Oxytropis (NS0039938), Poa (NS0039940, NS0039941), Thymus (NS0041214), and Trollius (NS0040012). We invite all interested specialists to view and, where possible, identify the specimens using the barcode numbers in the "Search" field in the Digital Herbarium of the CSBS (http://herb.csbg.nsc.ru:8081), or make a request to digitize some taxa from the checklist published in the dataset (Gatilova et al. 2021).

During the inventory of the sector, we did not check whether all the specimens were identified correctly, and did not relocate all specimens with names of synonyms on them to one place. However, the updated catalogue contains information about the presence of taxa, whose names are synonyms. The correct spelling of the Latin names of plants, as well as the currently accepted names, were verified using online databases Catalogue of life (Catalogue 2021) and The World Checklist of Vascular Plants (WCVP 2021).

At present, the RFE section of NS comprises 16174 herbarium sheets and 3248 species of vascular plants from 135 families. The largest families are Asteraceae (359 specimens), Poaceae (300), Cyperaceae (238), Rosaceae (173), Ra- nunculaceae (164), Fabaceae (141), Brassicaceae (117), Caryophyllaceae (117), Polygonaceae (99) and Salicaceae (84).

The digitization of the entire RFE section was not carried out, although we had earlier digitized the families Primulaceae, Geraniaceae, Salicaceae, the genera Allium, Rhododendron, Medicago, and the class Polypodiopsida, which also contain herbarium sheets from Russian Far East (GBIF 2021). All regions of the Russian Far East are represented among the digitized material.

Botanists from Russian Far East Institutes (S.S. Kharkevich, T.G. Buch, A.E. Kozhevnikov, I.B. Vyshin, V.Yu. Barkalov, V.V. Yakubov, T.I. Nechaeva, T.A. Bezdeleva, N.S. Probatova, and M.Yu. Gorshkov) contributed a significant part of herbarium material to RFE NS section as well as Siberian collectors such as I.M. Krasnoborov, V.M. Hanminchun, D.N. Shaulo, G.I. Gorohova, V.I. Telegin, N.N. Lashchinskii, and G.A. Fedoseev. Additionally, the section contains materials from the Amur integrated expedition of the Komarov Botanical Institute 1957-1958 (collections of G.N. Nepli).

Among the oldest specimens in RFE section of NS there are plants collected by N.A. Pal'chevskii in 1889-1909 from Primoye Territory. He was the Vice-president of the Society for the Study of the Amur Region. He worked as a forester, first in Suchan in 1893, and then as a military forester of the entire South Ussuri region in 1899-1907. Pal'chevskii was a friend of V.K. Arsen'ev, the famous Russian explorer of Far Eastern nature, who taught him scientific methods and accompanied him on the expedition in 1906 and also some of his previous expeditions (Anonymous 1912).

Some herbarium specimens were collected by S.I. Korzhinskii in 1891. The East Siberian Branch of the Russian Geographical Society sent him to the Amur Region to study the local flora and the suitability of the region for colonization. This expedition resulted in the publication of "Report on the study of the Amur region as an agricultural colony" (Korzhinskii 1892).

Some collectors of the early 20th century are listed below. Specimens gathered by them were sent to CSBG as exsiccata or duplicates mostly from the Komarov Botanical Institute RAS (LE).

F.K. Karo worked in 1903-1904 around Blagoveshchensk. Some plants collected by Karo were gathered on the right bank of Amur River (in China) and were mistakenly placed in Russian Far East section, but some are from Amur Region. I.M. Shchegolev was an entomologist who participated in the expedition in 1903 in Khabarovsk Territory (Shchegolev 1906). P.V. Syuzev was an artillery officer during the Russian-Japanese War and did a military service in 'Ussuriiskii Krai' (now Primorye Territory) in spring, 1905, and in China in summer, 1905 (Nikolaev 1958). In his free time, he collected herbarium specimens. Later in his publications 830 plant species from Chinese Manchuria were listed (Syuzev 1907). N.A. Desulavi was a botanist who lived in Khabarovsk, and participated in expeditions with V.K. Arsen'ev in 1907 and 1908 (Anonymous 1912). G.A. Fedoseev was a Siberian geodesist, who since 1938 supervised topographic works on the Angara River, on the Middle and Lower Tunguska, and explored the Yablo- 
novyi and Stanovoy Ridges, the Okhotsk Coast, and the Dzhugdzhur Ridge. Fedoseev also took part in the development of maps of the regions for the Bratskaya, Ust-Ilimskaya, Boguchanskaya and Zeyskaya hydroelectric power stations, and the Baikal-Amur Railway. Fedoseev knew a lot about the flora and fauna of the Russian Far East, collected many plants and birds from Siberia and the Russian Far East and donated all his collections to the Russian Academy of Sciences (Ermolenko 1999).

During the inventory of the RFE NS, the type specimens of the following taxa were found: Anemone tamarae Kharkev. (NS0000476), described from the Khabarovsk Territory from the gatherings by S.S. Kharkevich and V.V. Yakubov (Kharkevich 1981); Chrysosplenium schagae Kharkev. \& Vyschin (=Chrysosplenium pilosum Maxim. subsp. schagae (Kharkev. \& Vyshin) V.N. Voroshilov, NS0000477), described from the Khabarovskii Territory collected by I.B. Vyshin and S.S. Kharkevich (1985); Potentilla anjuica V.V. Petrovsky (NS0000479), described from the Magadanskaya Oblast (Petrovskii 1983). We have clarified the publication dates of the $P$. anjuica protologue, as they were misspelled in the text of the exsiccata.

The isotype of Tephroseris schistosa (Kharkev.) Barkalov (NS0000480), described from the collections of S.S. Kharkevich and T.G. Buch from Kamchatka in 1976, was also kept in RFE NS section, although in the protologue only the VLA herbarium is indicated as the place of isotype storage (Barkalov 1992). Recently, these herbarium specimens were specially prepared (Fig. 1), then digitized using ObjectScan 1600, entered into the CSBG SB RAS Digital herbarium and kept together with the protologue in the section of NS type specimens.

\section{CONCLUSION}

The inventory of the entire herbarium section showed that there were a lot of mismatches between the catalogue data and the real herbarium samples of the collection. Such an inventory is very useful for further digitizing of the collection. This process helps to verify the correct Latin names of plants, and clarify their placement in NS according to the geography of herbarium gatherings. The interesting facts about history and collectors were discovered during the inventory. The summary table with catalogue published by GBIF (Gatilova et al. 2021) is very convenient for study by specialists worldwide. Researchers interested in studying the taxa from Russian Far East are welcome to visit our collections and work with NS and NSK herbaria in comfortable conditions or make a special request for digitization of the herbarium specimens of interest.

\section{ACKNOWLEDGEMENTS}

The work was carried out within the framework of the State Assignment of the Central Siberian Botanical Garden, SB RAS № AAAA-A21-121011290024-5. The authors are grateful to I. Deyun and L. Lukmanova for their valuable help with insertion of the RFE NS section, and also to staff of the Vascular plant systematics laboratory for the physical removal of the herbarium specimens and for the plant determination. We thank Dr. Keith Chamberlain and Dr. Irina
Belyaeva (UK) for their useful linguistic corrections on the manuscript and our reviewers for their comments.

\section{LITERATURE CITED}

Anonymous 1912. Information about the expeditions of captain Arsen'ev (Travels in the Ussuri region) 1900-1910. Zapiski Priamurskogo otdela Imperatorskogo Russkogo geograficheskogo obshchestva 8(2):1-36 (in Russian). [Сведения об экспедициях капитана Арсеньева (Путешествия по Уссурийскому краю) 1900-1910 гг. // Записки Приамурского Отдела Императорского Русского Географического Общества. Хабаровск, 1912. Т. 8, вып. 2. С. 1-36].

Barkalov, V.Yu. 1992. Tephroseris schistosa. In: Vascularplants of the Soviet Far East, vol.6 (S.S. Kharkevich, ed.), p. 236, Nauka, Saint Petersburg (in Russian). [Баркалов B.Ю. 1992. Tephroseris schistosa // Сосудистые растения советского Аальнего Востока / под реА. С.С. Харкевича. Санкт Петербург: Наука. Т. 6. С. 236].

Catalogue of Life. [author list in alphabetical order] (ed.) 2021. Species 2000 \& ITIS Catalogue of Life, 2021-05-07. Digital resource at www.catalogueoflife.org. Species 2000: Naturalis, Leiden, the Netherlands. ISSN 2405-8858.

Ermolenko, G. 1999. Geodesist and writer Grigorii Fedoseev (On the centenary of the birth). Nauka v Sibiri 14(2200) (in Russian) [Ермоленко Г. 1999. Геодезист и писатель Григорий Федосеев (К столетию со Аня рожАения) // Наука в Сибири, № 14 (2200)].

GBIF. 2021. The Global Biodiversity Information Facility. Available from: https://www.gbif.org. Accessed on: 2021-05-21.

Gatilova, E.A., I.V. Han \& N.K. Kovtonyuk 2020. Digital inventory of the Foreign Asia section in I.M. Krasnoborov herbarium collection. Botanica Pacifica 9(2):155-159.

Gatilova, E, I. Han, N. Kovtonyuk, I. Shekhovtsova, A. Ebel, S. Ovchinnikova, V. Yakubov, N. Vlassova, I. Belyaeva 2021. Vascular plants checklist from Russian Far East section of I.M. Krasnoborov Herbarium (NS) at CSBG SB RAS. Version 1.3. Central Siberian Botanical Garden SB RAS. Checklist dataset https://doi.org/10.15468/9j59us accessed via GBIF.org on 2021-10-13.

Kharkevich, S.S. 1981. Anemone tamarae (Ranunculaceae) - a new species from the north of Khabarovskii Krai. Botanicheskii Zhurnal 66(11):1631-1635 (in Russian). [Xapкевич C.C. 1981. Anemone tamarae (Ranunculaceae) - новый виА с севера Хабаровского края / / Ботанический журнал. Т. 66, №11. С. 1631-1635].

Korzhinskii, S.I. 1892. Report on the study of the Amur Region as an agricultural colony. Izvestiza Vostochno-Sibirskogo otdela Russkogo geograficheskogo obshchestva 23(5):73-138 (in Russian). [Коржинский С.И. 1892. Отчет об исследовании Амурской области как земледельческой колонии // Известия Восточно-Сибирского отАела Русского географического общества. Иркутск. Т. 23, вып. 5. С. 73-138].

Kovtonyuk, N., I. Han, E. Gatilova. 2020. Vascular plants from European Russia in the CSBG SB RAS Digital Herbarium. Biodiversity Data Journal 8:e56504.

Nikolaev, S.F. 1958. Naturalist Pavel Vasil'evich Syuzev. Perm, 56 рр. (in Russian). [Николаев С.Ф. 1958. Испытатель природы Павел Васильевич Сюзев. Пермь. 56 с.].

Petrovskii, V.V. 1983. Two new species of the genus Potentilla (Rosaceae) from the North-East Asia. Botanicheskii Zhurnal 68(3):400-402 (in Russian). [Петровский В.В. 1983. Ава новых вила рода Potentilla (Rosaceae) с северо-востока Азии // Ботанический журнал. Т. 68, №3. С. 400-402].

Shchegolev, I.M. 1906. Through the Stanovoi ridge: (Survey of the Nelkan-Ayan tract. Expedition of 1903). Zemleve- 


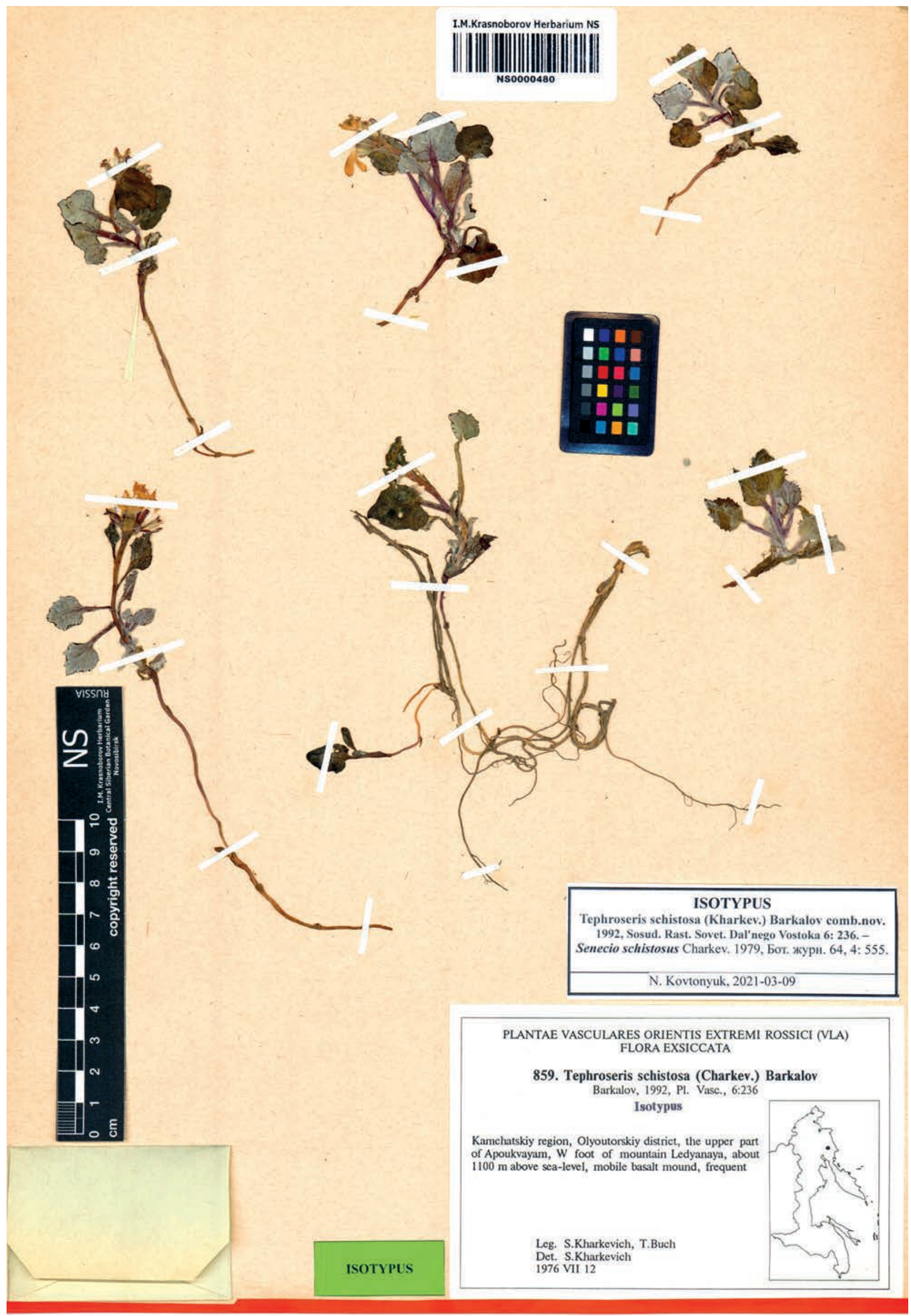

Figure 1 Isotype of the name Tephroseris schistosa (Kharkev.) Barkalov (NS0000480) 
denie 13(1-2):68-140; 13(3-4):1-33 (in Russian). Щегомев И.М. 1906. Через Становой хребет: (Изыскание Нелькан-Аянского тракта. Экспедиция 1903 г.) // Земмеведение. Т. 13, кн. 1-2. С. 68-140; кн. 3-4. С. 1-33].

Syuzev, P.V. 1907. Observations on the spring flora of the Ussuri region. Botanicheskii Zhurnal 4:87-105 (in Russian). [Сюзевъ П.В. 1907. Наблюденія надъ весенней флорою Уссурійскаго края // Ботаническій журналь. № 4. С. 87-105].

Thiers, B. (ed.) 2021. Index Herbariorum: A global directory of public herbaria and associated staff. New York Botanical Garden's Virtual Herbarium. Available from: http:/ / sweetgum. nybg.org/science/ih/ Last accessed 2021-05-21.
Vyshin, I.B. \& S.S. Kharkevich 1985. Two new species (Salix sichotensis - Salicaceae, Chrisosplenium schagae - Saxifragaceae) from Northern Sikhote-Alin. Botanicheskii Zhurnal 70(8):1120-1125 (in Russian). [Вышин И.Б., Харкевич С.С. 1985. Ава новых вила (Salix sichotensis - Salicaceae, Chrisosplenium schagae - Saxifragaceae) из северного Сихоте-Алиня // Ботанический журнал. Т. 70, №8. C. 1120-1125].

WCVP. 2021. World Checklist of Vascular Plants, version 2.0. Facilitated by the Royal Botanic Gardens, Kew. Available from: http://wcvp.science.kew.org/ Last accessed 21.05.2021. 